\title{
Auffindung des Winnecke'schen Cometen (1886 ...).
}

Am 21. Aug. Abends erhielt die Centralstelle folgendes Telegramm aus Capetown:

"Comet Winnecke unmusical Finlay unaptly August gallantness foully but fourth disappearence drag un\$happy convince. Astronomer royal Capetown. «

d.h. $\quad$ Der Winnecke'sche Comet wurde am 19. Aug. von Finlay aufgefunden und wurde beobachtet:

Aug. 20.2416 M. Z. Greenw. AR. $=197^{\circ} 35^{\prime} 22^{\prime \prime}, \quad P D .=91^{\circ} 8^{\prime} 17^{\prime \prime}$.

Comet circular, diameter $\mathrm{I}^{\prime}$, brightness $1 \mathrm{O}^{\mathrm{m}}$, some central condensation, no tail.

The Astronomer Royal, Capetown.k

Dies Telegramm wurde am 22. Aug. Vorm. an die Mitglieder der Centralstelle, ferner nach Rio de Janeiro, resp. Cordoba, und Melbourne weiter befördert. Die in Nr. 2720 der A. N. ausgesprochene Erwartung, dass die Sternwarten der südlichen Halbkugel bei der Aufsuchung des Cometen mitwirken wïrden, ist in der That in Erfullung gegangen, und die weitere Verfolgung in künftigen Erscheinungen wird, Dank den Bemühungen der Capsternwarte, jetzt eine sicherere Grundlage erhalten. Der Durchgang durch das Perihel hat gegen I 2 Tage früher stattgefunden, als nach Herrn A. Palisa in A. N. 2720 angegeben ist.

Kiel 1886 Aug. 22.

A. Krueger.

\section{On the Orbit of the Binary Star os 234.}

As far as I know the elements of the orbit of this binary have not hitherto been published. I have obtained the following elliptical elements by the graphical method in which the elements of the real ellipse are derived from the apparent ellipse by means of Thiele's harmonic ellipse. The components are of magnitudes 7, and 7.4, and the star has always been a close and difficult object to measure even with large telescopes. Some of the recorded measures are very discordant which renders the calculation of a satisfactory orbit difficult and uncertain. The following elements must therefore be considered as only provisional.

$$
\begin{aligned}
& \text { Elements of } O \Sigma 234 \text {. } \\
& \begin{array}{ll}
P=63.45 \text { years } & \delta=124^{\circ} 1 \mathrm{I}^{\prime}(1880.0) \\
T=188 \mathrm{1} \text {.1 } 5 & \lambda=715^{8} \\
e=0.3629 & a=0^{\prime \prime} 339 \\
\gamma=47^{\circ} 2 \mathrm{I} & \mu=+5^{\circ} 67
\end{array}
\end{aligned}
$$

These elements satisfy the observations fairly well from 1844 to 1853 , and from 1870 to 1880 , but in the years $185^{8-1866}$ the discordances are considerable, the greatest difference being at the epoch 1866.49 , at which date $\theta_{o}-\theta_{c}=+26.9$, but the star was recorded as »perhaps oblong * by O. Struve on this date and a note of interrogation (?) is appended to the measured angle. The position of the star for 1880.0 is:

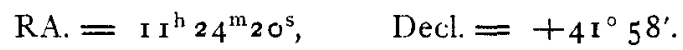

Ballysodare, Co. Sligo, Ireland, 1886 July 6.

F. E. Gore.

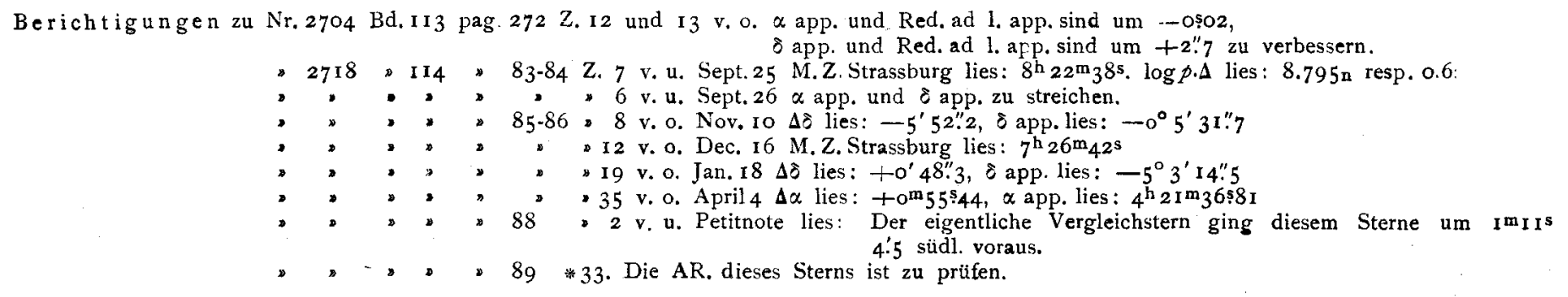

\section{Inhalt:}

Zu Nr. 2743. Todes-Anzeige. 97. - A. Hall. Comparison of the Observations of the five inner Satellites of Saturn. 97. - L. Stutz. Beob. achtungen von Planeten am Meridiankreise der Grossh. Sternwarte zu Karlsruhe. 105. - E. Lamp. Beobachtungen des Cometen $1886 \mathrm{II}$ (Barnard) am Refractor der Sternwarte in Kiel. 107. - C. W. Pritchett. Observations of Comets. 107. - H. Pomerantzeff. Observations de la comète $1886 \mathrm{II}$ (Barnard) faites à l'Observatoire de Tachkent. Io9. - E. Frisby. Observations of Comets. 109. -

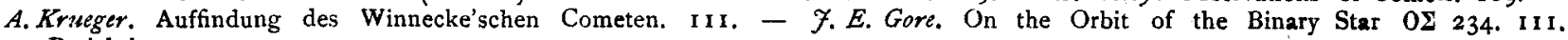
- Berichtigungell. I1 1. 